being attacked in this country partly by observations of pilot balloons and partly by observations near the earth's surface of the angle of elevation of a balloon, which in a horizontal wind floats very nearly at the same level as the point to which it is attached. Special difficulties arise owing to the rapid increase of the errors of observation in the first method as the balloon travels away from the observers, and to the influence of the instability of the wake in the second method. Dr. Ludewig's contribution will therefore be of special interest. $\mathrm{He}$ uses the principle that the barometer in the balloon shows the height above sea-level, and therefore the rate at which the balloon is rising relative to the earth, while a vertical anemometer carried by the balloon shows the rate at which the balloon rises relative to the air. The difference between the two rates gives the rate at which the air is rising relative to the earth or the strength of the vertical current.

The construction of a suitable anemometer is the principal difficulty. Dr. Ludewig uses a fan in a small cylinder, which hangs from the balloon in a vertical position; the revolutions of the fan are recorded photographically by an ingenious device, so that the inertia and friction are reduced to a minimum. When the anemometer was suspended in a horizontal current of air, the fan did not rotate, so that effects arising from variations in the horizontal velocity were practically eliminated. In addition to a barograph, a Bestelmeyer variometer was used. The instrument is a form of eye-reading microbarograph, which permitted of great accuracy in determining the small variations in altitude as the balloon travelled across the country. In the first ascent, made on January 22, 1911, the results obtained from the variometer and the anemometer agreed so closely that it was evident that no vertical currents were present. In the third ascent, on February 18 th, when there was a steep gradient for westerly winds over central Europe, strong vertical currents were experienced, and the instrumental measurements showed that the motion was mainly upwards, and reached at times a speed of 3 metres per second at altitudes slightly less than one kilometre. A curve, showing in profile the country passed over by the balloon during the period for which the diagram of vertical motion is drawn, would add interest to the latter and possibly suggest the causes of the rapid variations in the upward current.

E. GOLD.

\section{BEACH-LA-MAR, THE JARGON OF THE WESTERN PACIFIC.}

BACH-LA-MAR is that peculiar variety of English $B$ speech which has arisen from the contact of uncultured civilisation with the savage or semi-civilised peoples of the western Pacific. It is a language born of the necessity of comprehension between primitive traders, and is thus, in its nature and purpose, akin to the Lingua Franca of the Levant, the Pidgin of the China Seas, the Chinook of the American fur trade, the Negro-English of the Guiana plantations, and the Krooboy talk of the African coast. Its name suggests but one of its origins, for Beach-la-mar is the sailor's mispronunciation of Bêche-de-mer, a name of the Trepang or Holothuria, which was prepared on the island shores for the markets of the East Indies. But the language began with the American whalers and the sandalwood gatherers of the early nineteenth century, who preceded the bêche-de-mer fishers of the 'forties and 'fifties. On the decay of the trepang industry the talk passed to the copra-collectors and the beach-combers, and was finally settled as the jargon of the Pacific by the "blackbirding" (more delicately described as the "recruiting of Polynesian labour") in the 'sixties, when it became the common speech of the natives on the Queensland plantations.

Few have recorded the speech, and in an entertaining little volume $\mathrm{Mr}$. Churchill has noted all that is to be found relating to it, with some chapters by way of introduction. ${ }^{1}$

Mr. Churchill discusses the art of breaking English into jargon. It is delightfully simple, for " the proper way to make a foreigner understand what you would say is to use broken English." Politeness may give way to emphasis.

1 "Beach-la-mar, the Jargon or Trade Speech of tre Western Pacific." By William Churchill. Pp. 54. (Published by the Carnegie Institution of Washington, rgrr.)

NO. 2200, VOL. 88]
Grammar and the elegances of speech do not matter. The want of these will not shock the native, for in no native language is it possible to be ungrammatical. In them intelligible speech consists in the placing of the vocables in the right order. Inaccurate arrangement is unintelligible nonsense. The native subjects the broken English to the rules of his own speech. As to this, Mr. Churchill, premising that a single parent for the many and diverse languages of Melanesia is as yet unproved, recognises that all the languages of that region are practically on the same plane of development, and so uses the designation "Melanesian speech" to indicate a composite of the knowledge of the languages there spoken. He regards them as isolating languages, and rejects the Malayo-Polynesian theory of Bopp, as well as the application to them of the term " agglutinative." $\mathrm{He}$ believes the words may be separated into monosyllabic elements, and these even may be susceptible of ultimate reduction to vowels, to which may be prefixed or suffixed a consonant with a definite power of qualifying or fixing a special meaning to the stem.

The rules of isolating speech applied to the Broken English formed the Beach-la-mar.

The vocabulary is nearly all English, and the marine element is strong. Mr. Churchill says, "There can be no hesitation in ascribing to forecastle English such exotics as pickaninny, calaboose, and savvy-longshore sweepings from the Spanish Main. The squareface, sole landward hope of the sailor, is scarcely known ashore. The sailor dialect has kept alive, and has given to these remote savages the special sense of sing out and look out, of capsize along with copper, of slew, of look alive, of adrift and fashion. Of certain elements of low, cant, vulgar English the sailors may have been the carriers." The Kanakas in the Queensland plantations enriched the vocabulary with Austral English, and to this "we must ascribe in the greater measure the inclusion of such terms as tumble doren and blackfellow, of flash and trash, of hook it and clear out, of hump and zoire in, of gammon and bloody." Such words as kaikai food, likelik, little, tambo or tabu come from the island tongues, and one word, rauss (? clear out) is German.

Mr. Churchill has given a bibliography of the subject in fifteen entries. He has produced a most instructive and interesting book. It illustrates a simple language in the making, and records a form of speech which will disappear with colonisation and mission schools. It is to the presence of these in the Torres Straits that a decadence in jargon noted by Mr. Churchill is due.

SIDNEY H. RAY.

\section{THE FRACTURE OF FLINT BY NATURE} AND BY MAN.

$\mathrm{A} \mathrm{T}$ a meeting of the Prehistoric Society of East Anglia, held at Norwich on November 4 , the natural fracture of flint and its bearing on rudimentary flint implements was discussed by Mr. J. Reid-Moir.

Subjoined is a summary of the main points described :-

(I) Experiments were shown in natural percussion produced by placing a number of flint nodules in a sack and shaking them violently together. The following results were obtained :-

First, some of the flints were flaked on the edge by blows which had impinged at all angles, as would be expected from fortuitous blows.

Secondly, nearly all the blows had impinged obliquely, thereby blunting the edge and showing prominent ripplemarks.

On the other hand, human blows are always delivered at a constant angle to the edge of the flint, and are delivered vertically to the edge, as it is much easier to remove flakes thus than by oblique blows, which is nature's method.

Nature must of necessity detach flakes obliquely, because out of the 180 angles at which it is possible to edge-flake a flint, there is only one which gives a true vertical flake.

These vertical flakes do not show ripple marks, as the force of the blow does not pass through the body of the flint.

It was also seen that fortuitous blows produced a large number of truncated flakes on the edge of the flints, which are not seen to anything like such a large extent on human 
implements, as such flaking is not required in their manufacture. With fortuitous flaking the rain of blows is practically incessant, and truncated flakes are of necessity produced.

Many of the specimens shown exhibited marked sinuous edges, but the blows which caused them were all oblique and impinged at varying angles.

(2) Experiments were performed in natural pressure by means of an ordinary and a differential screw press (with a rubber $\mathrm{ram})$, giving a pressure ranging from 40 to 300 tons to the square inch.

It was found that through a thin layer of sand the pressure was incapable of fracturing the thinnest flint flakes.

On a hard surface, the pressure and resistance being equal, flakes were detached from flint nodules showing two bulbs, one at each end of the flake and opposite to each other.

In the case of a flake detached by percussion, only one buib occurs. Therefore this fact provides an excellen test for differentiating between man's work and flaking by natural pressure.

If the under surface on which the flint rests is not sufficiently resistant, a flake detached shows only one bulb, which is entirely different from that produced by percussion.

When a suitable flint is carefully placed upon another equally suitable, and pressure applied, a "hollow-scraper" can be produced showing much finer flaking than that resulting from percussion.

It is known that the finer flaking on Neolithic implements, such as arrow-heads and "pigmies," is always produced by pressure applied by man.

A large number of specimens was shown to illustrate each experiment described.

\section{THE MEDICAL WORK OF THE LOCAL GOVERNMENT BOARD.}

THE report of the medical officer of the Local Government Board for the year I9IO-II ${ }^{1}$ has been issued with commendable promptitude. Dr. Newsholme's report, which occupies the first seventy pages of the volume, gives a comprehensive review of the public health in rgro and of the work of the medical department of the Board, and epitomises some special subjects considered during the year, public vaccination, and the auxiliary scientific investigations carried out for the Board.

The review of the public health gives some of the more important facts as to the incidence of particular diseases, and a comparison is given graphically for the ten years 1901-10. It is gratifying to find that there has been a decline in the death-rate for all the following:-general death-rate, infant mortality, enteric fever, scarlet fever, diphtheria, puerperal diseases and accidents, and phthisis and tuberculous diseases. Measles alone has not markedly diminished. One of the most striking declines in the death-rate is that of enteric fever, which has diminished from about 16 per 100,000 in I9OI to about 4.5 in I910, a percentage decline of 70 , representing a saving of nearly I0,000 lives in I910 compared with I90I, and a financial saving estimated at $1,49^{2}, 800 \mathrm{l}$. Pulmonary tuberculosis (phthisis, consumption) was responsible for 38,639 deaths in 1909, still a heavy mortality; but had the same deathrate existed in this year as in $187 \mathrm{I}-80$ the deaths would have been 78,308 : this saving of life represents a financial saving of nearly six millions sterling. Preventive medicine may well be proud of such results as these!

The circumstances of the outbreak of plague in Suffolk are discussed, but these have already been dealt with in our pages.

Of the auxiliary scientific investigations, Dr. Gordon has once more studied the types of streptococci present in the fauces in scarlet fever. He has found that the scarlatinal streptococci are indistinguishable from streptococci present in other disease processes; this leaves the problem of the etiology of scarlet fever still unsolved. Infantile diarrhœea has been investigated by Dr. C. J. Lewis at Birmingham,

I Fortieth Annual Report of the Local Government Board, Igro-It Supplement containing the Report of the Medical Officer for Ig10-II.
Dr. S. M. Ross at Manchester, Dr. R. A. O'Brien at London, and Dr. T. Orr at Shrewsbury: Of diarrhœa cases, $49 \cdot 2$ per cent. yield non-lactose fermenting organisms from the fæces; of non-diarrhœea cases, only I9.I yield similar organisms, showing a much greater frequency of non-lactose fermenters in diarrhoea than in health. No one type of organism, however, has been found with sufficient frequency to justify the assumption that the disease is necessarily or usually attributable to one and the same organism.

Dr. Andrewes contributes a study of the bacteria present in the air of sewers and drains, a subject previously investigated by him for the Board in 1906-8. In the case of sewers, the dissociation of micro-organisms from the sewage is very small. In the case of drains, where there may be much more splashing than in sewers, organisms dissociated from the sewage may be far more numerous and may be carried by air currents in large numbers for considerable distances.

Dr. Inman has studied the secondary infections in pulmonary tuberculosis. He considers that in nearly every case of "open tuberculosis" of the lungs the tubercle bacillus is the predominant infecting agent.

R. T. Hewlett.

\section{THE HEDLEY GOLD FIELD, BRITISH \\ COLUMBIA.}

THE mining town of Hedley on the Similkameen River, in British Columbia, a little west of the roth meridian and about twenty miles north of the United States boundary, is the most important mining camp in that district, and is of interest owing to the unusual character of its ores. The town is situated near the mouth of the Twenty Mile Creek, a canyon from 2500 to 4000 feet deep and with walls sloping at angles of $40^{\circ}$. The first mining claims were discovered there in 1894 , and though many small mineral deposits have been found in the district, there are only two producing mines, the Nickel Plate and the Sunnyside Mines, of which the former is the most productive gold mine in Canada.

The country consists of Upper Palæozoic rocks, doubtfully identified as Carboniferous; they include a lower series of limestones, quartzites, and argillites, a middle series of limestones and quartzites-the Nickle Plate Formation and an upper series of tuffs and volcanic breccias-the Red Mountain Formation. The sedimentary series was invaded in early Mesozoic times by intrusions of gabbro and diorite. The ore deposits are unique in America, for they are contact metamorphic deposits containing arsenopyrite as the principal gold-bearing mineral. The ores are developed along the contacts between the gabbro and diorite with the sedjmentary deposits. The igneous rocks have metamorphosed the limestones, but have had a comparatively small effect on the quartzites, argillites, and tuffs. The mineralisation is greatest where the contact alteration is greatest, and though gold is found in all the sulphides the highest values occur in the arsenopyrite. The granodiorite has had comparatively little effect either as a source of metamorphism or of ores, and the gabbro has been far more active than the diorite. The gabbro forms the foot-wall or is closely associated with the ore bodies in the two producing mines and in some of the smaller ore deposits.

After the intrusion of the igneous rocks the field was faulted and fissured; but neither faults nor fissures are of much economic importance. The faults were later in date than the ore bodies, and the fissures are filled with barren veins of quartz and calcite, and contain no ore deposits of commercial value. The ores, in fact, do not occur in well defined lodes, but they grade off imperceptibly into barren country rock. As the ore deposits occur parallel to the bedding planes, it has been suggested that the gold was originally scattered through the sedimentary rock, and has been concentrated by the igneous activity; this suggestion was all the more natural, as the gold has been found widely distributed through the sedimentary rocks. It is found in them, however, only within the sphere of influence of the

1 "The Geology and Ore Deposits of Hedley Mining District, British Columbia." By C. Camsell. Canada Department of Mines Geological Survey Branch, Memoir No. 2. Pp. $218+x x$ plates +8 figs +4 maps. (Ottawa, ro10.) 